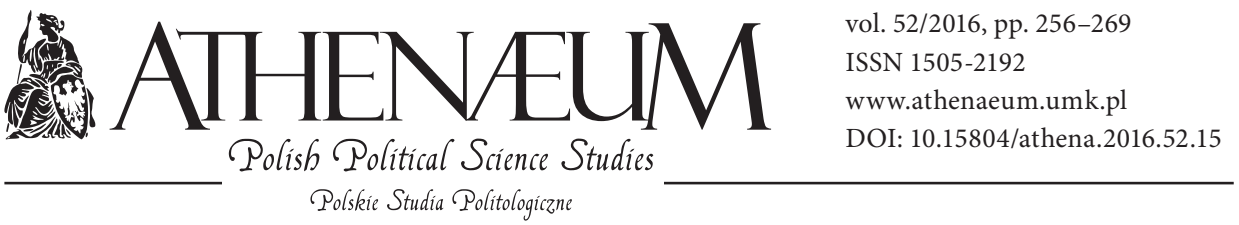

\title{
ANXIETY DETERMINANTS OF POPULIST ATTITUDES AMONG YOUNG PEOPLE
}

\author{
LĘKOWE UWARUNKOWANIA POSTAW POPULISTYCZNYCH \\ WŚRÓD OSÓB MŁODYCH
}

Danuta Plecka*, Agnieszka Turska-Kawa**

\begin{abstract}
In 2015, so-called double (i.e., presidential and parliamentary) elections were held in Poland. The unquestionable winner of these elections was Law and Justice [Prawo i Sprawiedliwość], using slogans such as "good change" or "we'll make it" in the campaign. The leitmotif of this campaign was discrediting any activities, including achievements, of the Civic Platform [Platforma Obywatelska] / Polish Peasant Party [Polskie Stronnictwo Ludowe] coalition, addressing a "simple man" or the nation, and pointing out the need to involve the state institutions to implement the "good change" in favor of the "simple man". Thus, Law and Justice adopted the anti-elitist position, pointing to the "pathologies of democracy in Poland", mainly caused by the rule of the Liberals. Initiating the populist style of thinking was one of the reasons for the party's success. This was an interesting research problem for us, especially that Law and Justice gained the trust of many young voters, aged 18-24.
\end{abstract}

ABSTRAKT

W 2015 roku w Polsce odbyły się tzw. podwójne wybory: prezydenckie i parlamentarne. Niekwestionowanym zwycięzcą tych elekcji zostało Prawo i Sprawiedliwość, posługujące się w kampanii wyborczej między innymi takimi hasłami wyborczymi, jak „dobra zmiana” czy „damy radę”. Lejtmotywem kampanii było dyskredytowanie wszelkich działań, w tym także osiągnięć koalicji rządowej Platforma Obywatelska-Polskie Stronnictwo Ludowe, zwracanie się do „prostego człowieka”, narodu, a także wskazywanie na konieczność uruchomienia instytucji państwa w celu realizacji „dobrej zmiany” na rzecz tegoż „prostego człowieka”. Tym samym PiS zajęło pozycję antyelitystyczną, wskazując na „patologie demokracji w Polsce”, których przyczyną były przede wszystkim rządy „liberałów”. Uruchomienie populistycznego stylu myślenia było jedną, choć nie jedyną, przyczyną sukcesu ugrupowania. Zwróciło to naszą uwagę badawczą,

${ }^{*}$ Nicolaus Copernicus University in Toruń, Faculty of Political Sciences and International Studies.

${ }^{* *}$ University of Silesia in Katowice, Institute of Political Sciences and Journalism. 
The success of Kukiz'15 Election Committee, based on the third place achieved by musician Paweł Kukiz in the presidential election, was also very significant for our research questions. It was fascinating because Kukiz'15 Electoral Committee, apart from the popular slogan about the need to establish single-member electoral districts (JOW) and anti-elitist approach, did not offer the voters any vision of socio-political order in terms of ideology or programme. Still, it managed to persuade citizens to vote for Kukiz'15 in the parliamentary election.

These premises led to a research problem concerning the analysis of anxiety determinants that contributed to the positive reaction of voters, especially young ones, to the populist elements of the electoral campaign. Obviously, the fact that so-called soft populism is an inherent characteristic of all electoral campaigns was taken into account. Furthermore, we took into consideration the widespread occurrence of populist slogans in virtually all political programmes. Still, some questions remained unanswered, and the aim of the present study was to answer them. The primary question to answer is about the degree to which individual anxiety dispositions influence the development of populist attitudes among young people. Another important question is whether these are strong populist attitudes or just populist tendencies. The research results presented below are exploratory in character: this is only an introduction to further search for the answers to the above-mentioned questions.

Keywords: anxiety, populism, young elector tym bardziej że PiS zdobył duży poziom zaufania wśród młodych wyborców, w wieku 18-24 lata. Duże znaczenie dla stawianych przez nas pytań badawczych miał także sukces Komitetu Wyborczego Kukiz'15, stworzonego na bazie zagospodarowywania sukcesu odniesionego przez muzyka Pawła Kukiza w wyborach prezydenckich (trzeci wynik). KW Kukiz'15 bowiem, poza nośnym hasłem o konieczności stworzenia jednomandatowych okręgów wyborczych (JOW) oraz antyelityzmem, ideowo i programowo nie oferował wyborcom żadnej wizji porządku społeczno-politycznego. Pomimo to udało się przekonać obywateli do pomysłu oddania głosu na Kukiz' 15 w wyborach parlamentarnych.

Powyższe przesłanki spowodowały pojawienie się problemu badawczego dotyczącego analizy lękowych uwarunkowań, które przyczyniły się do pozytywnej reakcji wyborców, szczególnie osób młodych, na populistyczne wątki w kampanii wyborczej. Oczywiście pod uwagę został wzięty fakt, że tzw. miękki populizm jest nieodłączną cechą wszystkich kampanii wyborczych. Ponadto uwzględniono także powszechność haseł populistycznych - ich obecność w zasadzie we wszystkich programach politycznych. Pomimo to pozostały pytania, na które przeprowadzone badania miały dać odpowiedź. Do podstawowych należy przede wszystkim to, w jakim stopniu dyspozycje lękowe jednostki wpływają na kształtowanie się postaw populistycznych wśród osób młodych. Nie mniej ważne jest pytanie, czy mamy do czynienia ze zdecydowanymi postawami populistycznymi, czy jedynie $\mathrm{z}$ tendencjami populistycznymi wśród młodych. Zaprezentowane poniżej wyniki badań mają charakter eksploracyjny - są jedynie wstępem do dalszych poszukiwań odpowiedzi na postawione pytania.

Słowa kluczowe: lęk, populizm, młody wyborca 


\section{INTRODUCTION}

In 2015, so-called double (i.e., presidential and parliamentary) elections were held in Poland. The unquestionable winner of these elections was Law and Justice [Prawo i Sprawiedliwość], using slogans such as "good change" or "we'll make it" in the campaign. The leitmotif of this campaign was discrediting any activities, including achievements, of the Civic Platform [Platforma Obywatelska] / Polish Peasant Party [Polskie Stronnictwo Ludowe] coalition, addressing a "simple man" or the nation, and pointing out the need to involve the state institutions to implement the "good change" in favour of the "simple man". Thus, Law and Justice adopted the anti-elitist position, pointing to the "pathologies of democracy in Poland", mainly caused by the rule of the Liberals. Initiating the populist style of thinking was one of the reasons for the party's success. This was an interesting research problem for us, especially that Law and Justice gained the trust of many young voters, aged 18-24.

The success of Kukiz'15 Election Committee, based on the third place achieved by musician Paweł Kukiz in the presidential election, was also very significant for our research questions. It was fascinating because Kukiz'15 Electoral Committee, apart from the popular slogan about the need to establish single-member electoral districts (JOW) and anti-elitist approach, did not offer the voters any vision of socio-political order in terms of ideology or programme. Still, it managed to persuade citizens to vote for Kukiz'15 in the parliamentary election.

These premises led to a research problem concerning the analysis of anxiety determinants that contributed to the positive reaction of voters, especially young ones, to the populist elements of the electoral campaign. Obviously, the fact that so-called soft populism is an inherent characteristic of all electoral campaigns was taken into account. Furthermore, we took into consideration the widespread occurrence of populist slogans in virtually all political programmes. Still, some questions remained unanswered, and the aim of the present study was to answer them. The primary question to answer is about the degree to which individual anxiety dispositions influence the development of populist attitudes among young people. Another important question is whether these are strong populist attitudes or just populist tendencies. The research results presented below are exploratory in character: this is only an introduction to further search for the answers to the above-mentioned questions. 


\section{POPULISM - AN IDEOLOGY OR AN ATTITUDE?}

Populism is a heterogeneous category and phenomenon that occurs in many areas of social and political life. According to Pierré-Andre Taguieff (as cited in Nalewajko, 2013, p. 40), some premises for the development of populism are the activation of the dissatisfied, the presence of a charismatic leader (both of them likely to occur in authoritarian, presidential and semi-presidential systems), the lack of a uniform ideology (which means that conservative and progressive attitudes coexist), and the belief that the virtue is in the simple people, being the vast majority, and their collective tradition (Wiles, 2010, p. 25). This can also be supplemented with the idea of change in social relations, characteristic for populism, although this change is not necessarily tantamount to progress. The intervention of the state as the institution that solves the problems of the "simple people" plays a role here, too.

Populism is regarded to be a very common phenomenon and often mistaken for demagogy (Szacki, 2007, p. 10; Karwat, 2006, p. 225-230). This is mostly the result of quite thoughtless use of the term 'populism', even applied as an insult, typically with reference to politicians, regardless of their party affiliation, especially by the media. The concept of populism has actually become the weapon of opponents of certain individual or collective political actors, aimed at discrediting them. We tend to forget that populism, as a widespread phenomenon (Szacki, 2007, p. 11), is apparently moving from the peripheries to the centres of the contemporary world. The context in which populism is discussed nowadays is, first of all, the perspective of Western political democracy, although it was only

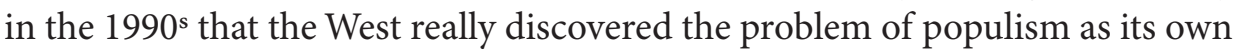
problem (Szacki, 2007, p. 12).

A question emerges, therefore, what the premises of contemporary populism are actually based on, if it is not a concrete ideology. Jerzy Szacki rightly observes that populism is not really about particular ideas, values, or institutionalization of the masses. Populism is a special understanding of democracy (Szacki, 2007, p. 14), which cannot be described using commonly known patterns. Thus, although it is a common phenomenon, it is hard to grasp. Populism not only refers to manipulations applied by politicians but first of all is the expression of dissatisfaction of people's masses, which manifest it in any possible way: often not very professionally but very emotionally. This is fostered by the so-called "empty core", pointing out the populists' lack of attachment to any values or ideas: the values and ideas are selected depending on the current needs of the activists. That 
is why it is so easy to find populist attitudes in activists identifying with great ideologies, such as conservatism or liberalism. It should also be underscored that populism draws both on the ideas of the left and right wing, and quite often serves as a counterbalance to the leading ideologies. It is supplemented by the "heartland", being the embodiment of the customs and wisdom of the people. The occurrence of this principle in all types of populism is partly explained by the fact that this construct is idealized very much within a community. It can even be regarded as a specific kind of founding myth forced through in politicians' utterances and actions. The "heartland" is obviously inhabited by people, and the people gives meaning to all interpretations and invocations from populists (Taggart, 2010, p. 84).

Both the "empty core" and the "heartland" are the elements populists resort to in crisis situations. It is worth mentioning here that populists are generally against the political system, especially against its representative formula, and against being engaged in politics. They even consider functioning in a party and parliament configuration to be abhorrent, since both institutions are barriers to achieving the set goals. The paradox is that politics is the only form in which populists can manifest their views.

Despite the negative attitude to politics and activity in its organized form, there are situations when populists become active in it. These are crisis situations. Truly, it is very difficult to objectively say what socio-political situations are considered as critical ones. Hence, a crisis may be the effect of belief in the occurrence of crisis, not the actual socio-political condition. As Paul Taggart observes, populism emerges when a serious process of changes causes the sense of crisis at least in one social group (Taggart, 2010, p. 80). At the same time, this social group is characterized by growing self-awareness and the sense of separation from power centres.

It is worth emphasizing that these social groups usually have low social, economic and civic competence. It is mainly promoted by the anti-intellectualism of populism and the already mentioned association with the category of "people" and their inherent traditions. Another important belief is that anti-intellectualism has one more significant task: it is negation, escape from anything that symbolizes the elite of a certain community. Hence, it provides the basis for building the "new order".

Populism is a substitution category, often used as an insult because it cannot be classified and presented from the perspective of the known ideological models or patterns connected with ideological divisions and standards of thinking which 
prevailed in the West at the turn of the $21^{\text {st }}$ century. It is also a specific strategy of action for the community, and thus, it can undoubtedly help achieve very different goals. The main dimension of populism, understood in this manner, is the instrumental one (Dzwończyk, 2000, p. 18).

\section{ANXIETY AS A PERSONALITY TRAIT}

Just like populism, anxiety is an ambiguous and multidimensional term. In source literature, there are many approaches and concepts whose aim is to grasp the specific features of anxiety reactions. The first psychological concept of anxiety was developed by Sigmund Freud. He defines anxiety as a negative subjective state one gets into because of the perception of increasing excitation of the organism resulting from the development of a certain affect, e.g., sexual arousal, aggression, or hatred (Freud, 1957, p. 354-355). The psychoanalytical concept of anxiety was also presented by Calvin S. Hall (1995, p. 61). The author defines anxiety as a negative emotional experience caused by the stimulation of the organism, which may occur as a result of a stream of stimuli from the inside or the outside and is controlled by the autonomic nervous system (when a person faces new, dangerous or unclear situation, their heart begins to beat more quickly, hands begin to sweat, the throat goes dry, etc.). Anxiety differs from other negative experiences in that it persists in one's consciousness. Karen Horney (as cited in Siek, 1993, p. 260-261), originating from the circle of psychoanalysts, emphasizes that anxiety is the response to a danger, which involves physiological reactions such as sweating, trembling, or heat pounding. She considers this danger to be hidden and subjective. Horney underscores that anxiety is one of the most tormenting experiences. This persistence of reactions is connected with the fact that anxiety is permanent and the person becomes helpless in the face of it. Thus, he or she is helpless in the face of something that mostly has no rational explanation, which may lead to the development of low self-esteem. Raymond Cattell (1966, p. 36-38), in turn, defines anxiety from the operational perspective, as groups of reactions and reaction patterns related to anxiety, e.g., uneasiness, excitation, or irritation. Edward J. Murray (1964, p. 252-255) points out that the disposition to experience and reveal anxiety reactions is inborn, but its development greatly depends on whether the closest environment provides the person with anxiety causing or anxiety reducing stimuli. 
When analysing concepts of anxiety originating from different psychological schools, it must be emphasized that most authors define anxiety as a group of emotional reactions that can be evoked both by external and internal stimuli and have the following characteristics:

a) are perceived as a negative and persistent state,

b) are accompanied by the sense of helplessness and irrationality,

c) coexist with physiological reactions of the organism, such as quickened heart rate, quick breathing, higher blood pressure, quicker metabolism, or a set of opposite reactions: lower heart rate, stupor, and an urge to urinate,

d) authors identify different kinds of anxiety. Raymond Cattell identifies 'anxiety as a state', which involves a broad range of identical response patters, repeated in a similar form, independently of the stimuli that cause them, and 'anxiety as a trait', which differs from the state with the duration and recurrence of anxiety reactions (1966, p. 36-38).

Experiencing persistent anxiety reactions and helplessness in the face of these states is the source of even more anxieties, which may lead to changes in self-perception. In order to defend themselves from negative feelings, individuals apply different defence mechanisms. Anna Freud identifies the following most common defence mechanisms: repression - a sudden and uncontrollable removal of the threatening impulse, thought, image, or memory; introjection - taking over the beliefs and/or behaviours from an esteemed person; isolation - the loss of contact with the feeling associated with a traumatic event with retained consciousness of cognitive details: emotions remain out of the awareness; denial - blocking access to consciousness for any external event that is temporally or symbolically associated with a threatening impulse (in: Strelau, 2006, p. 666). According to Karen Horney, there are four main techniques of coping with anxiety: rationalization - looking for possible logical explanations for the incident of anxiety; denial of anxiety - repression, suppression, efforts to reduce external anxiety responses; substance abuse - reducing the anxiety by taking drugs, drinking alcohol, or excessive sleeping; avoidance of thoughts or impulses that may evoke anxiety - avoiding any situations than may cause anxiety reactions (as cited in Siek, 1993, p. 45-47).

The authors of the work are particularly interested in the differentiation between anxiety reactions made by some researchers: anxiety as a state and anxiety as a trait (disposition). Dispositional anxiety is especially significant when we refer it to personality psychology. In the light of contemporary psychology, we understand a personality trait as a relatively permanent, individual, general- 
ized tendency to certain behaviours, expressed in different situations consistent with this tendency (Strelau, Doliński, 2008, p. 771). Thus, the anxiety trait is understood as a behavioural motivation or disposition which makes a person susceptible to perceiving a broad spectrum of objectively harmless situations as dangerous and responding to them with anxiety states, disproportionately strong given the seriousness of the objective danger (Sosnowski, Wrześniewski, 1983, p.. In this definition, special role is attributed to cognitive processes, which play a considerable role in an anxiety causing situation. In this respect, some stability of anxiety responses occurs. Stanisław Siek (1993, p. 271) emphasizes that when we use the expression 'anxiety trait', we may have in mind either a relatively permanent consistent pattern of anxiety behaviour, which differentiates the individual from other persons (the understanding of a trait by Joy Paul Guilford ${ }^{1}$ ), or a disposition, hypothetical power organizing certain anxiety reactions, a hypothetical neuropsychological system of the person, initiating and controlling anxiety behaviours (the understanding of a trait by William Stern ${ }^{2}$ ). The development of traits is determined by internal mechanisms, which are inborn or acquired, but they are also affected by a number of other factors. Thus, the tendency to react or behave in a certain way has a genetic basis, but it can be modified by ontogenetically developing physiological mechanisms and by other environmental factors that influence the individual (Strelau, Doliński, 2008, p. 772).

Anxiety understood as a disposition is a relatively permanent quality of the person, and its development is to a great extent determined by internal mechanisms. Anxiety as a trait is latent and cannot be observed directly. It is a variable mediating between the stimulus that has an impact on the person and the person's reaction. Anxiety cannot be directly perceived, and its level estimated, unless the person is in a situation conducive to the revelation of that trait, a situation in which certain stimuli influencing the person actually cause anxiety. Then, the trait is revealed in the person's reactions.

1 He identifies a personality trait as a relatively permanent, distinct pattern of behaviour, different from other persons.

2 According to him, a personality trait is a disposition that purposefully organizes sets of actions and psychological phenomena. 


\section{RESEARCH MODEL}

In a situation of anxiety, cognitive processes play a significant role, potentially distorting the received message. They make a person react quickly, often on the basis of stereotypes, typical patterns, and heuristics. Populism, with its specific rhetoric, is supposed to fit the communication pattern desired by persons with high level of anxiety. Populism is often identified with agitation and demagogy, or a little more broadly, treated as a strategy, a style of action, and a method of political discourse (Taggart, 1995; Minkenberg, 2002). Following Cas Mudde (2007), it must be highlighted that a fundamental aspect of populism is perceiving the society from the perspective of a division into two homogeneous and antagonistic groups: the people and the corrupted elite, accompanied by the belief that politics should be the expression of general will of the society. In addition, as argued by Paul Taggart, Yves Meny and Yves Surel, populists express the view that politics is filled with corrupt behaviours to the brim, while real virtue and chastity are inherent to the people (Taggart, 2002, p. 76). Maintaining this division on the basis of highlighting the "us" and "them" borderline will draw on fears, anxieties and clear objection to the existing order, since negation and opposition to the existing situation is pointed out as the key element in the system of values upheld by the populists and the proposed ways of achieving their goals (Laclau, 2000, p. 17).

Activation of the people, being the centre of the world's vision for the populists, requires a specific message, which will be a tool to activate broader circles of the forming community. Populism makes use of popular superstitions and stereotypes as the tools of social activation (e.g., by short, catchy slogans), it also gives simple answers to complex questions; usually, however, these solutions are unrealistic. This rhetoric mostly fits the issues full of emotion, reflecting people's problems in the face of which they are often helpless (e.g., crime, prices, taxes, or patriotism). These problems may be additionally exaggerated by people with high anxiety disposition.

The subject of the analysis is dispositional anxiety, but it needs to be emphasized that persons with high anxiety disposition also display an increased tendency to experience situational anxiety. It may mean that in such people it is much easier to arouse fears and anxieties based on the current socio-political situation and the negation of the existing "threatening" order. Providing properly formulated messages that offer simple solutions to the experiences of anxiety may prove to be the desired response to persistent feelings of anxiety connected with the socio-political situation. 
On the other hand, in a threatening situation individuals activate a number of defence mechanisms aimed at the elimination of the negative sensations connected with the occurrence of anxiety. As a result, when experiencing anxiety related to the socio-political situation, a person can decide to activate the defence mechanism involving complete withdrawal from the area of influence of messages connected with the problem. This may lead, for example, to not engaging in the narratives of the election campaign, discussions on the topics proposed by politicians, not reading articles on the subject, etc.

In our study, the main research question was: Is dispositional anxiety a predictor of populism among young people? The analysis involves differentiation of the respondents in terms of sex, place of residence, and the monthly amount of money the respondent has.

\section{RESEARCH METHODOLOGY AND OBJECTIVES}

The study was carried out among 153 people aged 18-24, including 96 women $(62.7 \%)$ and 57 men (37.3\%). There were 63 rural residents (41.2\%) and 90 urban residents $(58.8 \%)$.

The diagnosis of the level of dispositional anxiety was conducted with the use of Inwentarz Stanu i Cechy Lęku (Form X-2). It is an adaptation of the American State-Trait Anxiety Inventory (STAI) drawn up by Charles D. Spielberger, Richard L. Gorsuch, and Robert E. Lushene. According to Charles D. Spielberger, dispositional anxiety should be understood as relatively permanent individual differences in the inclination to experience anxiety states. Anxiety as a trait is an indicator of individuals' potential capabilities to react in stressful situations. It can also be expected that people displaying stronger anxiety disposition experience anxiety as a state more often than others do when they are in new situations, unclear situations, or situations they perceive as threatening (Siek, 1993, p. 303).

The indicator of populist tendencies were the responses given in an original scale, originally made up of 15 statements (e.g., "Balcerowicz must go away", "Donald Tusk is to blame", or "You have to steal the first million"). The participants were asked to respond to each of them using a five-point scale ("strongly disagree", "disagree", "hard to say", "agree”, or "strongly agree”). In the preliminary part of the research procedure, the designed tools for diagnosing populism were verified. The conducted analysis of discriminatory power of the test items showed 
weak factor loadings of 6 statements, which were then excluded from further analysis. Finally, a 9-item instrument was used in the analysis.

\section{RESULTS}

In the study, young people were asked to express their opinion on the statement ending the sentence "As I think of Poland,.... These statements were slogans functioning in the public space, also during the electoral campaigns after 1989, such as apparently the most famous one, "Balcerowicz must go away". Out of the 15 prepared statements, only 9 had satisfactory factor loadings. These were: "The state should provide jobs for the unemployed, The poor will always be poor and the rich will always be rich, More of the state in the economy, You have to steal the first million, I pay taxes and expect the state to give me healthcare, education, a job, etc., Do whatever you want, Donald Tusk is to blame, Poland deserves an economic miracle, The state should care about work safety".

The final form of the scale indicates the coexistence of populist attitudes in different dimensions. This first of all refers to the role of the state and antiintellectualism (identified with political elites). With regard to the statement Donald Tusk is to blame, which reflects the strongest populist tendencies, it can be said that the participants could not see any positive effects of the rule of the Civic Platform. This is also confirmed by the level of correlation of the statement Poland deserves an economic miracle. This result indicates strong antiintellectualist tendencies, being a form of objection to political elites. It must also be remembered that this statement reflects a tendency towards social changes. Taking into account the character of changes Poland has been undergoing after the presidential and parliamentary elections of 2015 (not evolutionary but rather revolutionary), it can be said that the analyzed slogan and the level of correlation indicate clear populist tendencies among the young generation.

A separate and distinct group was comprised of the statements referring to the role of the state, such as: "The state should provide jobs for the unemployed, More of the state in the economy, I pay taxes and expect the state to give me healthcare, education, a job, etc., The state should care about work safety". This group shows that a strong populist trend is emerging, clearly pointing to the role the state should serve. At the same time, this group includes solutions of basic social problems (e.g., unemployment), which on the one hand are a "prediction" 
of a social change, and on the other hand can be used by "people's spokesmen" to influence the vision of the "new order" and manipulate the "people".

Three statements, Do whatever you want, You have to steal the first million, The poor will always be poor and the rich will always be rich, deserve to be analyzed separately. The obtained study results lead to the thesis that they reflect certain attitudes, such as disappointment with the political and economic system and anti-elitist approach, and they are the basis for a specific style of thinking about democracy.

The study produced a positive correlation between the populism and dispositional anxiety variables $r=0.23$ at the significance level 0.01 . This outcome confirms some relations but also general differences between the dimensions.

Table 1. Descriptive statistics for the analyzed variables with consideration of participants' sex and place of residence

\begin{tabular}{|l|c|c|c|c|c|}
\hline Variable & Sex & $\mathrm{N}$ & Mean & $\begin{array}{c}\text { Standard } \\
\text { deviation }\end{array}$ & $\begin{array}{c}\text { Standard error } \\
\text { of mean }\end{array}$ \\
\hline \multirow{4}{*}{ Populism } & women & 96 & 3.0891 & .49642 & .05067 \\
\cline { 2 - 6 } & men & 57 & 3.1871 & .62657 & .08299 \\
\cline { 2 - 6 } & town & 63 & 3.0171 & .55340 & .06972 \\
\cline { 2 - 6 } & village & 90 & 3.1265 & .54311 & .05725 \\
\hline \multirow{4}{*}{ Dispositional anxiety } & women & 96 & 2.2185 & .44259 & .04517 \\
\cline { 2 - 6 } & men & 57 & 1.9783 & .42398 & .05616 \\
\cline { 2 - 6 } & town & 63 & 2.0650 & .45028 & .05673 \\
\cline { 2 - 6 } & village & 90 & 2.1739 & .44633 & .04705 \\
\hline
\end{tabular}

Source: original study.

The mean populism ration of the respondents was $3.12(\mathrm{SD}=0.548)$; there were no statistically significant differences between men and women and between urban and rural residents. The mean dispositional anxiety of the respondents was $2.12(\mathrm{SD}=0.450)$ and was significantly higher for women than for men $(\mathrm{df}=151$, $t=3.296, p=0.001$ ). The place of residence did not differentiate between the level of dispositional anxiety. It is worth noting that the mean scores concerning dispositional anxiety in our study were around sten 4 , both for men and for women.

In order to verify the level of prediction of the populism dependent variable on the basis of the level of dispositional anxiety, univariate regression analysis was carried out. Dispositional anxiety is a poor explanation for the level of 
populism: the R-square value for the univariate model was 0.055 , which means that dispositional anxiety explains $5.5 \%$ of the variance. The model is statistically significant; the value of $\mathrm{F}$ statistics is $(1,151)=8.753, \mathrm{p}=0.004$.

Table 2. Estimation of the regression coefficient for dispositional anxiety

\begin{tabular}{|c|c|c|c|c|c|}
\hline \multirow[t]{2}{*}{ Model } & \multicolumn{2}{|c|}{$\begin{array}{l}\text { Non-standardized } \\
\text { coefficients }\end{array}$} & \multirow{2}{*}{$\begin{array}{l}\text { Standardized } \\
\text { coefficients }\end{array}$} & \multirow[t]{2}{*}{$\mathrm{t}$} & \multirow[t]{2}{*}{ Significance } \\
\hline & B & Standard error & & & \\
\hline (Constant) & 2.412 & .246 & & 9.790 & .000 \\
\hline $\begin{array}{l}\text { Dispositional } \\
\text { anxiety }\end{array}$ & .335 & .113 & .234 & 2.959 & .004 \\
\hline
\end{tabular}

Source: original study.

\section{SUMMARY}

Anxiety is one of weak but significant predictors of adopting populist attitudes, so it gives the potential for further research. We are aware that our sample was small, but we want to emphasize that this was an exploratory study which opens the way for subsequent analyses. However, our research enables us to conclude that some populist tendencies occur in the group of young people we studied, being first of all a consequence of politicians taking over anxiety dispositions. The occurring tendencies cover all the aspects of populism: both the ones concerning the "heartland", and the "lack of hard core". Anti-elitism and demanding attitude towards the state and its role in the contemporary society were also very strongly articulated.

\section{ReFERENCES:}

Cattell, R.B. (1966). Anxiety and Motivation: Theory and Crucial Experiments. In: Ch.D. Spielberger (ed.), Anxiety and Behavior (p. 23-62). New York: Academic Press. Dzwończyk, J. (2000). Populistyczne tendencje w społeczeństwie postsocjalistycznym (na przykładzie Polski). Toruń: Wydawnictwo Adam Marszałek.

Freud, Z. (1957). Wstęp do psychoanalizy. Warszawa: Wydawnictwo Książka i Wiedza. 
Hall, C.H. (1955). A Primer of Freudian Psychology. London: Penguin Group.

Horney, K. (1947). The Neurotic Personality of Our Time. London: Kegan Paul. As cited in: Siek, S. (1993). Wybrane metody badania osobowości (p. 260-261). Warszawa: Wydawnictwo ATK.

Laclau, E. (1977). Politics and Ideology in Marxist Theory. Capitalism, Fascism, Populism. London: NLB.

Minkenberg, M. (2002). The Radical Right in Postsocialist Central and Eastern Europe: Comparative Observations and Interpretations. East European Politics \& Societies, $16(2), 335-362$.

Mudde, C. (2007). Populist Radical Right Parties in Europe. Cambridge: Cambridge University Press.

Murray, E.J. (1964). Sociotropic-Learning Approach to Psychotherapy. In: P. Worchel, D. Byrne (eds.), Personality Change (p. 249-288). New York: Wiley.

Sosnowski T., Wrześniewski K. (1983). Polska adaptacja inwentarza STAI do badania stanu i cechy lęku. Przegląd Psychologiczny, 26 (2), 393-411.

Siek, S. (1993). Wybrane metody badania osobowości. Warszawa: Wydawnictwo ATK.

Strelau, J. (2006). Psychologia różnic indywidualnych. Warszawa: Wydawnictwo Naukowe Scholar.

Strelau, J., Doliński, D. (eds.) (2008). Psychologia. Podręcznik akademicki. Gdańsk: Gdańskie Wydawnictwo Psychologiczne.

Szacki, J. (2007). Wstęp. In: Y. Meny, Y. Surel (eds.), Demokracja w obliczu populizmu (A. Gąsior-Niemiec, transl.) (p. 9-26). Warszawa: Oficyna Naukowa.

Taggart, P. (1995). New Populist Parties in Western Europe. West European Politics, $18(1), 34-51$.

Taggart, P. (2002). Populism and the Pathology of Representative Politics. In: Y. Meny, Y. Surel (eds.), Democracies and the Populist Challenge (p. 62-80). New York: Palgrave Macmillan. DOI: 10.1057/9781403920072_4.

Taggart, P. (2010). Populizm, lud i rdzenna kraina. In: O. Wysocka (ed.), Populizm (p. 77-98). Warszawa: Wydawnictwo Uniwersytetu Warszawskiego.

Taguieff, P.A. (2007). Le populisme et la science politique. In: J.P. Rioux (ed.), Les populismes (p. 17-59). Paris: Éditions Perrin. As cited in: Nalewajko, E. (2013). Między populistycznym a liberalnym. Style polityczne w Polsce po roku 1989 (p. 40-41). Warszawa: Instytut Studiów Politycznych PAN.

Wiles, P. (2010). Syndrom, nie doktryna: kilka podstawowych tez o populizmie. In: O. Wysocka (ed.), Populizm (p. 25-43). Warszawa: Wydawnictwo Uniwersytetu Warszawskiego. 